THURSDAY, JULY 25, 1907.

\section{DILLENIAN MEMORIALS AT OXFORD.}

The Dillenian Herbaria: an Account of the Dillenian Collections in the Herbarium of the University of Oxford, together with a Biographical Sketch of Dillenius, Selections from his Correspondence, Notes, \&c. By G. Claridge Druce Edited, with an introduction, by Prof. A. Vines, F.R.S. Pp. cxii +258 . (Offord the Clarendon Press, 1907.) Price I2s. 60. p

THIS volume is a valuable contribution to the history of helbotanic preeminence of Oxford in the first/ialf of the eighteenth century. It is significant that the three men Carl Linnæus visited in 1736 were Sir Hans Sloane, Philip Miller, and Dillenius. His credentials to the first were a commendatory letter from Boerhaave; but Sloane was then seventysix, he had seen the rise and fall of many botanic arrangements, was a follower of our own John Ray, whose system he had adopted when indexing his large collections of plants, and was averse to further change. To him the young Swede of twenty-nine, with a brand new scheme of his own, was a visionary to be dismissed with speed, and therefore, with a few cold compliments, Linnæus departed. With Philip Miller, the gardener to the Company of Apothecaries at Chelsea, he became acquainted, bringing with him letters from his patron Clifford, and a mutual appreciation was the result. The residence of Dillenius at Oxford was the chief attraction which drew Linnæus to that place; there he stayed a month, and might have shared the liberal offer of Dillenius to divide the emoluments of the professorship between them had he so wished.

At this time Dillenius had been only two years installed as Sherardian professor, though he had received the stipend from the death of William Sherard. His tenure of the chair from 1734 to his death in I747 was a bright interlude between two uneventful periods.

Mr. Druce has drawn up this account of the collections left by Dillenius, and has critically examined the specimens preserved as vouchers, illuminating many doubtful passages in the third edition of Ray's "Synopsis," and practically disposing of the dubious entries which have troubled many subsequent botanists. For studies of this character the facilities offered at the Botanic Garden, Oxford, are extremely good, and only to be excelled by the Sloane volumes in the department of botany, Cromwell Road. Mr. Druce has performed a labour of love in bestowing the work of years on these collections, and should be encouraged to persevere until all the more important of the pre-Linnean herbaria at Oxford are enumerated in similar detail. It should not be forgotten that the types of Sibthorp's splendid "Flora Græca" are also preserved at Oxford.

The introduction by Prof. Vines is an appreciative essay on the position of Dillenius as regards his contemporaries; then, with a single page of preface, Mr. Druce gives a life of Dillenius and bibliography, a

$$
\text { NO. I969, VOL. 76] }
$$

full selection from his extant correspondence. (the letters from Linnæus have, unhappily, disappeared), and thus, after an ample preamble, the principal portion of this volume begins.

Part v. opens with the collation of the Dillenian edition of Ray's "Synopsis " issued in I724, with the plants preserved in that special herbarium. This edition was practically the chief guide of British botanists for something like forty years, in fact unti1 Hudson's "Flora Anglica" superseded the Raian method by the Linnean system and nomenclature. We have for the first time an authoritative statement of what is in the herbarium, and what stands there for any given name.

Next and in similar fashion we find an account of the specimens representing the plates and descriptions in the "Hortus Elthamensis," that account of the garden of James Sherard the plates of which were etched by Dillenius. Following this we come to the great work of the author, the "Historia Muscorum," with a prefixed statement of the authorities whose determinations are the basis of the modern reductions; errata and index close this interesting volume.

The temptation to dwell longer on this theme is strong, but must be resisted; the book vividly recalls days spent long ago amongst these very plants and manuscripts, and this notice must end with the hope that another instalment from this treasure house may in due time be forthcoming.

B. D. J

\section{THE FOURTH INTERNATIONAL}

ORNITHOLOGICAL CONGRESS.

Proceedings of the Fourth International Ornithological Congress, London, June, 1905, forming Vol. xiv. of the "Ornis." Editgs under the direction of the Presidert D P. R. Bendler Sharpe, by the Secretariff, D. En S J. O. Hartert and J. Lewis Aonhole. 10C696; with 18 plates. (London: Dulay fand fo., 1907.) Price 21s, net.

$A^{S}$ fh many other branches of science, the ornithA ologists have established an international congress, and the official account of their fourth meeting, held in London in June, 1905 , is now before us. It forms a handsome and well-illustrated volume of 696 pages, and constitutes also the fourteenth volume of Ornis, the official journal of the association, which accompanies the presidency of the congress when it is moved from one country to another.

The first meeting of the International Congress of Ornithologists was held at Vienna in April, I884, under the presidency of Dr. Gustav Radde, of Tiflis, and owes its inception, more or less, to the ill-starred Crown-Prince Rudolph of Austria, who had a certain amount of interest in natural history, inspired chiefly, we believe, by one of the Brehms, his personal friend and companion. The meeting at Vienna was a success to a certain extent, and was followed seven years later by the second meeting, which took place at Budapest in $189 \mathrm{r}$. This congress was very well attended, and was carried out with great éclat by the enthusiastic naturalists of the Hungarian capital. English ornithology was represented by the 